\title{
THE INFLUENCE OF DIET HABITS, ON WHAT, HOW, HOW MUCH AND FOR WHOM TO PRODUCE IN THE AGRICULTURAL SECTOR OF SERBIA?
}

\author{
Slavoljub Vujović ${ }^{1}$, Dušica Cvijanović ${ }^{2}$, Nenad Vujić ${ }^{3}$ \\ *Corresponding authorE-mail: kelovic1967@yahoo.com
}

\begin{abstract}
A R T I C LE I N F O
Original Article

Received: 13 November 2020

Accepted: 04 December 2020

doi:10.5937/ekoPolj2004205V

UDC 639.3.043.2:658.893(497.11)
\end{abstract}

Keywords:

agricultural sector, food, producers, households

\begin{abstract}
A B S T R A C T
The assumption that the questions of what, how, how much and for whom to produce are of paramount importance for all producers in the agricultural sector of Serbia, is the reason for researching the relationship between socio-demographic variables income of the respondent's household, the number of household members and the number of household members earning income) and eating habits, in order to collect information on what the population of Serbia consumes or wants to consume, and in what quantities.
\end{abstract}

(C) 2020 EA. All rights reserved.

JEL: Q10, Q11, Q18, Q19.

\section{Introduction}

Agriculture, from the smallest to the largest spheres of human development, is a fundamental activity or the starting point of human existence. Written traces testify that the economy, in ancient times, around $6000 \mathrm{BC}$, was based on agriculture, livestock and trade, while some authors cite 13,000 years (Montgomery, 2008), and some point out that agriculture played a crucial role in transforming society and population growth (Kremer, 1993). Developmental problems of economics and agriculture, in the form of questions: what, how, how much and for whom to produce was long ago formulated by the famous Nobel laureate Paul Samuelson (Economics, 1969) In the time of the Greek city-states and the Athenian Empire, and later in the time of Rome, the main economic branch of both Greece and Rome was agriculture (Galbraith, 2017). The well-known British economist and priest Malthus (Thomas Robert Malthus) linked the growth and

1 Slavoljub Vujović, Senior research associate, Institute of economics, Kralja Milana street N¹6, Belgrade, Serbia, Phone: +38163 365101, E-mail: kelovic1967@yahoo.com, ORCID ID (https://orcid.org/0000-0002-0686-3486)

2 Dušica Cvijanović, MA, Elementary school "Vožd Karađorđe” Jakovo, Boljevačka br. 2, 11276 Jakovo, Serbia, Phone +381 637817 240; Email: dusicanikolic14@gmail.com., ORCID ID (https://orcid.org/0000-0002-5220-465X)

3 Nenad Vujic, Research associate, Institute of economics, Kralja Milana street $\mathrm{N}^{\circ} 16$, Belgrade, Serbia, Phone: , E-mail: nenadvujicvuja@mts.rs, ORCID ID (https://orcid.org/00000002-6716-4056) 
survival of the population, in his scientific analyzes, directly with agriculture through the production of livelihoods (Vujović, 2007). Numerous studies and scientific papers confirm the importance of nutrition for the health of the population (Niva, 2007; Grupa autora, 2013; Ronteltap, et al., 2012; Popescu et al., 2017), that numerous diseases occur due to diet (Nikolić, et al., 2009). Aristotle himself (384-322 BC) in his works analyzing the essential categories of economics and ethics, never questioned the fundamental position of agriculture (Bulliet et al., 2011; Burešova et al., 2020). Wellknown theorists of economics Smith, Ricardo, Marx, Keynes, Leontief and others had a similar relationship, after Aristotle throughout history. However, there were those like Hume (David Hume 1711-1776) who, speaking of economic development and manufacturing, created doubts, claims such as "could not remember a single passage of any ancient author in which the growth of a city attributed to the establishment of manufacture" (Galbraith, 1995,7). Through the privatization process dictated by representatives of large international corporations - primarily the IMF, the WB, local experts, and national governments - the benefits of privatizing institutions and resources from across society have been transferred to private companies (Băncescu et al., 2019). Poverty is on the rise in Third World countries, especially in Latin America and Africa, where local elites have been more zealous in implementing "structural adjustment programs". Thus, e.g. Costa Rica after decades of disciplined implementation of structural adjustment programs, among other things, switched to food imports, increased the trade deficit by almost $100 \%$, from 350 to 532 million dollars (Lappe, M.F. et al., 1998.8). "The actors - governments, schools, producers, retailers, the media and consumers - can encourage $\mathrm{CE}$ by the production, distribution, consumption and presentation of the benefits of domestic food products" (Rakić, et al., 2019, 350; Wambui et al., 2019). Worldwide, 800 million people suffer from hunger every day. Every year, 12 million children die from hunger and diseases related to it, of which 34,000 are younger than 5 years (Lappe, M.F. and others, 1998.8). According to the Food and Agriculture Organization of the United Nations (FAO), food production has been growing faster since 1950 than population growth in all areas except Africa. Africa has enormous untapped potential to produce food, while countries known as famine countries $\square$ Somalia, Ethiopia, Sudan, for example $\square$ have much more unused land than they cultivate (Heilig, 1996), implying the importance of knowledge factors (Vilke, Gedminaite-Raudone and Cvijanovic, 2019:143), while Hungary can be cited as an example of a country that has an internationally respected agricultural sector and processes a significant part of its products in its own food industry (Juhász, et al., 2016). Some theorists, analyzing the multiple problems from which most agricultural and nutrition statistics suffer, warn that countries that have only recently modernized without exception underestimate their agricultural production (Poleman, 1981), while some authors point to the importance of agricultural policy and institutional support (Cvijanović et al., 2011). It should be noted that external influences and effects of production processes are very important for the agricultural sector (Tirol, 2016). 
Today, the concept of agrarian and rural development should have primarily broader economic-ecological-tourist motives, valorizing agro-ecological and rural potentials, in order to productive and socio-demographic revitalization of rural areas and more balanced demographic development (Milanović, et al., 2007,189; Greenwood, J., Williams, MA, Shaw, G. 1990; Cvijanović et al., 2019; Cvijanović et al., 2020). Some authors emphasize the direct impact of results achieved in agriculture on improving the quality of life in rural areas and the efficiency of the rural economy (Cvijanović et al., 2020: 19), while some point to the importance of clusters in agricultural and agricultural sector development (Porter, 2000). A direct impetus to the development of the agricultural sector in Serbia (Tošović-Stevanović, et al., 2020), through gastronomy, is provided by tourism, while e.g. ecotourism with all the positive aspects-insisting on preserving or not disturbing the natural environment, directly conditioned by a healthy environment and healthy food (Williams, A.M, 1988). Some world-famous researchers (Trišić, 2019) see the necessity of environmental protection as a common goal and direct connection of development aspects of tourism and agriculture, while the tourist market enables the agricultural sector to sell food products Cvijanović and others). In order to find an adequate answer to the questions: what, how, how much and for whom to produce, a field research was done on a very heterogeneous sample, given that all members of the population are consumers of food products. For all innovation capacities in agriculture, in addition to technological and management goods, information is needed (Pomareda, 2013), especially when it comes to the impact on the health of the population of certain food products (Sima \& Gheorghe, 2017; Khandpur et al., 2020).

\section{Sample and materials}

A total of 220 respondents participated in the research, of which 144 respondents $(65.5 \%)$ were male and 76 respondents $(34.5 \%)$ were female. Observed by age groups, the respondents were divided into six groups: $1.8 \%$ of respondents were under the age of $20,5.5 \%$ of respondents were in the age category between 20 and 30 , then $32.7 \%$ of respondents were in the age category between 31 and 40 years of age, $41.8 \%$ of respondents were in the category between 41 and 50 years of age, then in the group of 51 to 65 years of age $10.9 \%$ of respondents, and $7.3 \%$ of respondents were over 65 years of age. When the respondents are observed according to their employment status, $70.9 \%$ of employees, $18.2 \%$ of the unemployed, $1.8 \%$ of students and $9.1 \%$ of pensioners were in the sample. Regarding the acquired education, in this sample there were $36.4 \%$ of respondents with completed high school, $50.9 \%$ of respondents with completed college or university, while $10.9 \%$ of respondents have completed a master's or doctorate. When it comes to the amount of personal monthly income, $6.2 \%$ of respondents stated that they do not earn personal income, $41.8 \%$ of respondents earn up to 500 euros, $27.3 \%$ earn between 501 and 1000 euros, 12.7\% earn between 1001 and 1500 euros, $3.6 \%$ of respondents earn between 1501 and 2000 euros, and 3.6\% of respondents earn over 2000 euros per month. In addition to personal income, respondents were asked about the monthly income of the household and are therefore divided into several groups, $25.5 \%$ of respondents live in a household with an income of up to 500 euros per 
month, $29.1 \%$ of respondents state that they live in a household in which the income is from 501 to 1000 euros per month, in the category of income between 1001 and 1500 euros per month is $20 \%$ of respondents, in the category between 1501 and 2000 euros of income is $10.9 \%$ of respondents, in the category between 2001 and 3000 euros $3.6 \%$ of respondents have a monthly income, while $9.1 \%$ of respondents live in households with incomes higher than 3000 euros, while $1.8 \%$ of respondents stated that they are not familiar with this information. Observing the number of household members, it was shown that $12.7 \%$ of respondents live independently, $36.4 \%$ of respondents live in a two-member household, $21.8 \%$ live in a three-member household, $21.8 \%$ in a fourmember household, $1.8 \%$ live in a five-member household, while $5.5 \%$ of respondents live in a household with over five members. Regarding the division of respondents according to how many members of their households earn income, it is shown that in $36.4 \%$ of respondents only one member earns income, in $54.5 \%$ of respondents two members earn income, in $7.3 \%$ of respondents three household members earn income, while in households where four members earn income, $1.8 \%$ of respondents live.

\section{Subject, goal and research methodology}

The subject of the research was to examine the relationship between socio-demographic variables (gender, age, level of education, employment status, monthly personal income of the respondent and monthly personal income of the respondent household, number of household members and number of household members earning income) and eating habits in order to collect relevant information in response to questions: what, how, how much and for whom to produce in the Serbian agricultural sector. This research was of quantitative type and was conducted through a questionnaire in which the first part of the question referred to socio-demographic data about the respondent, while in the second part a group of dependent variables was processed through the Likert rating scale, to what extent they agree with the claims by which we examined their eating habits. For data analysis, we used: descriptive analysis (frequencies, percentages, arithmetic mean), t-test, multiple linear regression, and Pearson correlation coefficient. The level of statistical significance was set at $\mathrm{p}<0.05$, and all obtained data were processed in the SPSS program, version 19. The independent variables in this study were gender, age, level of education of the respondents, work status of the respondents, monthly personal income of the respondents, monthly income of the household, number of members living in the household and number of household members earning income. Dependent variables examined the eating habits of the respondents, who assessed on a five-point Likert type scale the extent to which they agreed with the statements examined, where 1 meant I did not completely agree, and 5 meant I completely agreed.

The results show that $80 \%$ of respondents regularly consume fresh fruits and vegetables, while $90.9 \%$ of them state that they can buy fresh fruits and vegetables in the immediate vicinity. The largest number of respondents $(61.9 \%)$ state that they do not consume fast food often, while almost every other respondent $(54.6 \%)$ points out that they do not consume snacks and sweets often. A sufficient amount of water is 
taken in by $65.4 \%$ of the respondents every day, while every other respondent $(50.9 \%)$ states that he does not drink milk often. Non-carbonated juices are not often drunk by $47.3 \%$ of respondents, while the number is higher when it comes to carbonated juices, which $63.6 \%$ of respondents state that they do not drink often. Low-alcohol beverages are not often drunk by $56.4 \%$ of respondents, while $81.8 \%$ rarely or strongly do not drink strong alcoholic beverages. Slightly less than half of the respondents (47.3\%) state that they are physically active, while $41.9 \%$ of the respondents state that they do not do sports. When it comes to whether GMO food is harmful, the largest number of respondents $(81.8 \%)$ believe that it is. That's right, $45.4 \%$ of respondents state that the most important thing when choosing food is that it is delicious, that $12.7 \%$ of respondents state that the most important thing for them is that it is low in calories, while for $45.5 \%$ it does not matter that the food is low in calories. When choosing food, $80 \%$ state that the most important thing for them is that it is healthy.

Table 1. Respondents' answers to what extent agree with the defined statements

\begin{tabular}{|l|c|c|c|c|c|c|}
\hline & $\mathbf{1}$ & $\mathbf{2}$ & $\mathbf{3}$ & $\mathbf{4}$ & $\mathbf{5}$ & NA \\
\hline $\begin{array}{l}\text { 1. I regularly consume fresh fruits and } \\
\text { vegetables }\end{array}$ & $1.8 \%$ & $1.8 \%$ & $16.4 \%$ & $50.9 \%$ & $29.1 \%$ & $/$ \\
\hline $\begin{array}{l}\text { 2. I can buy fresh fruits and vegetables in my } \\
\text { immediate vicinity, that is. it is available to } \\
\text { me }\end{array}$ & $1.8 \%$ & $1.8 \%$ & $5.5 \%$ & $54.5 \%$ & $36.4 \%$ & $/$ \\
\hline $\begin{array}{l}\text { 3. I often consume fast food } \\
\text { 4. I often consume snacks and sweets }\end{array}$ & $16.4 \%$ & $45.5 \%$ & $23.6 \%$ & $12.7 \%$ & $1.8 \%$ & $/$ \\
\hline 5. I take in enough water daily & $3.6 \%$ & $3.6 \%$ & $25.5 \%$ & $30.9 \%$ & $34.5 \%$ & $1.8 \%$ \\
\hline \begin{tabular}{l} 
6. I often drink milk \\
\hline 7. I often drink non-carbonated juices
\end{tabular} & $23.6 \%$ & $27.3 \%$ & $14.5 \%$ & $29.1 \%$ & $5.5 \%$ & $/$ \\
\hline \begin{tabular}{l} 
8. I often drink fizzy juices \\
\hline 9. I often drink weaker alcoholic beverages
\end{tabular} & $27.3 \%$ & $21.8 \%$ & $27.3 \%$ & $21.8 \%$ & $1.8 \%$ & $1.8 \%$ \\
\hline 10. I often drink strong alcoholic beverages & $54.5 \%$ & $27.3 \%$ & $10.9 \%$ & $5.5 \%$ & $1.8 \%$ & $/$ \\
\hline \begin{tabular}{l} 
11. I am physically active \\
\hline
\end{tabular} & $12.7 \%$ & $7.3 \%$ & $27.3 \%$ & $30.9 \%$ & $16.4 \%$ & $5.5 \%$ \\
\hline \begin{tabular}{l} 
12. I do sports \\
\hline 13. I find GMO food harmful
\end{tabular} & $25.5 \%$ & $16.4 \%$ & $29.1 \%$ & $16.4 \%$ & $12.7 \%$ & $/$ \\
\hline $\begin{array}{l}\text { 14. When choosing food, the most important } \\
\text { thing for me is that it is delicious }\end{array}$ & $3.6 \%$ & $18.2 \%$ & $32.7 \%$ & $30.9 \%$ & $14.5 \%$ & $/$ \\
\hline $\begin{array}{l}\text { 15. When choosing food, the most important } \\
\text { thing for me is that it is low in calories }\end{array}$ & $16.4 \%$ & $29.1 \%$ & $41.8 \%$ & $10.9 \%$ & $1.8 \%$ & $/$ \\
\hline $\begin{array}{l}\text { 16. When choosing food, the most important } \\
\text { thing for me is that it is healthy }\end{array}$ & $.0 \%$ & $3.6 \%$ & $16.4 \%$ & $50.9 \%$ & $29.1 \%$ & $/$ \\
\hline
\end{tabular}

*1-I do not completely agree; 2-I disagree; 3-Not sure; 4-I agree; 5-I agree completely; NA- no answer. Source: author's research. 


\section{T test}

The $\mathrm{T}$ test examined whether respondents differed in their responses to dependent variables in which eating habits were assessed depending on the gender to which they belonged. The T-test shows that the respondents differ in terms of regular consumption of fresh fruits and vegetables, $\mathrm{t}(218)=-4.26, \mathrm{p}<0.01$. It is shown that they are more regular in consuming fresh fruits and vegetables $(M=4.32)$ than men $(M=3.89)$. Thus, it is shown that the respondents differ in the frequency of drinking carbonated juices, $\mathrm{t}(218)=2.285, \mathrm{p}<0.05$ and it is shown that men $(\mathrm{M}=2.36)$ drink carbonated juices more often than women $(\mathrm{M}=2.00)$. Then, it is shown that the respondents differ according to the frequency of drinking strong alcoholic beverages $\mathrm{t}(218)=2,551, \mathrm{p}<0,05$. It is shown that men $(\mathrm{M}=1.83)$ drink strong alcoholic beverages more often than women $(\mathrm{M}=1.53)$. Regarding the choice of food in terms of choosing food to be low in calories, in this case there are differences between respondents $\mathrm{t}(218)=2,418, \mathrm{p}<0,05$, so men $(\mathrm{M}=2,64)$ to a greater extent than women $\mathrm{M}=2.32$ ) state that the most important thing when choosing food is that it is low in calories. Finally, it is shown that the respondents differ in that the most important thing when choosing food is that the food is healthy $t(218)=2.244$, $\mathrm{p}<0.05$. It is shown that men $(M=4.14)$ to a greater extent than women $(M=3.89)$ state that the most important thing when choosing food is that it is healthy. No statistically significant differences between the sexes were obtained for the assessment of other dependent variables.

\section{Multiple regression}

Multiple regression examined whether a combination of predictors, which included gender, age, employment status, level of education, monthly personal income, monthly household income, number of household members, and number of household members earning income, could predict habits, in the diet of the subjects. When it comes to regular consumption of fresh fruits and vegetables, they show that this combination of predictors can predict regular consumption of the mentioned $\mathrm{R}^{2}=.200, \mathrm{~F}(8,211)=6,595$, $\mathrm{p}<.01$, and as individual significant predictors the sex of the respondents $b=.369$, $\mathrm{t}=3.213, \mathrm{p}<.01$ and monthly personal income $\mathrm{b}=.143, \mathrm{t}=2.242, \mathrm{p}<.05$, which means that women with higher earnings consume fruits and vegetables more regularly than other categories of respondents. The results show that the availability of fresh fruits and vegetables can be statistically significantly predicted by this combination of predictors $\mathrm{R}^{2}=.134, \mathrm{~F}(8,211)=4,076, \mathrm{p}<.01$, and the age of the respondents $\mathrm{b}=-.132$ stands out as individual significant predictors, $\mathrm{t}=-2.368, \mathrm{p}<.05$, employment status $\mathrm{b}=.157, \mathrm{t}=2.187$, $\mathrm{p}<.05$, monthly household income $\mathrm{b}=.180, \mathrm{t}=3.599, \mathrm{p}<.01$ and number of household members $\mathrm{b}=-.154, \mathrm{t}=-3.070, \mathrm{p}<.01$. Based on the results, it can be concluded that fresh fruits and vegetables are more accessible to younger unemployed respondents with a higher household income, but numerically smaller household, and they can buy it in the immediate vicinity. A statistically significant prediction was obtained for the frequency of respondents in consuming fast food $\mathrm{R}^{2}=.163, \mathrm{~F}(8,211)=5.126, \mathrm{p}<.01$, and as individual significant predictors are the working status $\mathrm{b}=-.326, \mathrm{t}=-3.735$, 
$\mathrm{p}<.01$ and monthly household income $\mathrm{b}=-.174, \mathrm{t}=-2.871, \mathrm{p}<.01$, which means that employed respondents with lower monthly household income consume fast food more often than other groups of respondents. The frequency of consumption of snacks and sweets can also be statistically significantly predicted by this combination of predictors $\mathrm{R}^{2}=.214, \mathrm{~F}(8,211)=7.190, \mathrm{p}<.01$, and as individual significant predictors the gender $\mathrm{b}=.329, \mathrm{t}=2.531, \mathrm{p}<.05$, age of respondents $\mathrm{b}=-.159, \mathrm{t}=-2.462, \mathrm{p}<.05$, employment status $\mathrm{b}=.308, \mathrm{t}=3.692, \mathrm{p}<.01$ and monthly household income $\mathrm{b}=-.157, \mathrm{t}=-2.718$, $\mathrm{p}<.01$. Based on the results, it can be concluded that younger unemployed women with lower monthly household income consume snacks and sweets more often than other categories of respondents.

This combination of predictors proved to be statistically significant when the intake of sufficient water in the body at the daily level $\mathrm{R}^{2}=.112, \mathrm{~F}(8,207)=3,271, \mathrm{p}<.01$, and as individual significant predictors are the age of the respondents $\mathrm{b}=-.186, \mathrm{t}=$ $-2.451, \mathrm{p}<.05$ and working status $\mathrm{b}=.309, \mathrm{t}=3.154, \mathrm{p}<.01$, which means that younger unemployed respondents consume a sufficient amount of water in the body more than other categories of respondents. When it comes to the frequency of drinking carbonated juices, the results show that this combination of predictors can predict the mentioned frequency $\mathrm{R}^{2}=.074, \mathrm{~F}(8,211)=2.113, \mathrm{p}<.05$, and the working status $\mathrm{b}=-$ stands out as an individual significant predictor. $299, \mathrm{t}=-2.637, \mathrm{p}<.01$, which means that employed respondents drink carbonated juices more often than other groups of respondents. A statistically significant prediction was also obtained with the frequency of drinking weaker alcoholic beverages $\mathrm{R}^{2}=.197, \mathrm{~F}(8,207)=6,355, \mathrm{p}<.01$, and monthly personal income $\mathrm{b}=-.206, \mathrm{t}=-2,212$ stand out as individual significant predictors, $\mathrm{p}<.05$ and the number of household members earning income $\mathrm{b}=-.319, \mathrm{t}=-2.078, \mathrm{p}<.05$. Based on the results, it can be concluded that lower alcoholic beverages are more often drunk by respondents with lower personal incomes who live in households where a smaller number of members earn income. The results show that the frequency of drinking strong alcoholic beverages can also be statistically significantly predicted by this combination of predictors $\mathrm{R}^{2}=.263, \mathrm{~F}(8,211)=9.406, \mathrm{p}<.01$, and as individual significant predictors the pole $b=-.445, t=-3.423, p<.01$, age of respondents $b=.245, t=3.786, p<.01$, degree education $=.548, \mathrm{t}=5.727, \mathrm{p}<.01$, monthly personal income $\mathrm{b}=-.150, \mathrm{t}=-2.072, \mathrm{p}<.05$ and the number of household members earning income $b=.284, t=2.371, p<.05$. The obtained results show that older, more educated men with lower personal incomes, who live in households in which a larger number of members earn income more often than other groups of respondents, drink stronger alcoholic beverages. The physical activity of the respondents can also be statistically significantly predicted by this combination of predictors $\mathrm{R}^{2}=.199, \mathrm{~F}(8,199)=6.185, \mathrm{p}<.01$, and the age of the respondents $\mathrm{b}=$ $-.220, \mathrm{t}=-2.521$ are singled out as individual significant predictors, $\mathrm{p}<.05$ and monthly household income $b=.265, \mathrm{t}=3.385, \mathrm{p}<.01$, which means that younger respondents with higher household income are more physically active compared to other categories of respondents. This combination of predictors proved to be statistically significant when playing sports $\mathrm{R}^{2}=.277, \mathrm{~F}(8,211)=10,125, \mathrm{p}<.01$, and as individual significant 
predictors the pole $b=-.367, t=-2.090, p<.05$, age of respondents $b=-.204, t=-2.336$, $\mathrm{p}<.05$, monthly household income $\mathrm{b}=.363, \mathrm{t}=4.641, \mathrm{p}<.01$ and number of household members $b=.185, t=2,345, p<.05$. Based on the results, it can be concluded that younger men with higher monthly household incomes and a larger number of household members are more likely to play sports than is the case with other groups of respondents.

A statistically significant prediction was obtained in the opinion on the harmfulness of GMO food $\mathrm{R}^{2}=.142, \mathrm{~F}(8,211)=4,347, \mathrm{p}<.01$, and the age of the respondents $\mathrm{b}=.195$, $\mathrm{t}=2,612, \mathrm{p}<.05$ and the number of household members $\mathrm{b}=.215, \mathrm{t}=3.188, \mathrm{p}<.01$, which means that older respondents who live in a larger household more than other groups of respondents believe that GMO food is harmful. It is shown that the importance of food taste can be statistically significantly predicted during its selection. $\mathrm{R}^{2}=.090$, $\mathrm{F}(8,211)=2,594, \mathrm{p}<.05$, and the degree of education $\mathrm{b}=-.238, \mathrm{t}$ stands out as individual significant predictors $=-2.097, \mathrm{p}<.05$ and monthly personal income $\mathrm{b}=.192, \mathrm{t}=2.223$, $\mathrm{p}<.05$, which means that it is more important for respondents with lower education and higher personal income when choosing food that it is tasty than other categories of respondents. When it comes to the choice of food, the importance that it is low in calories, it is shown that this combination of predictors can predict its importance $\mathrm{R}^{2}=.228, \mathrm{~F}(8,211)=7.812, \mathrm{p}<.01$, and as individual significant predictors the gender $\mathrm{b}$ stands out $=-.414, \mathrm{t}=-3.208, \mathrm{p}<.01$, age of respondents $\mathrm{b}=.227, \mathrm{t}=3.544, \mathrm{p}<.01$, working status $b=-.456, t=-5.507, p<.01$, level of education $b=.365, t=3.851, p<.01$ and monthly household income $b=-116, t=-2.023, p<.05$. Based on the results, it can be concluded that when choosing food for younger highly educated employed men with lower household income, it is more important than other categories of respondents that it is low in calories.

This combination of predictors proved to be statistically significant in the importance that respondents give to healthy food when choosing food $\mathrm{R}^{2}=.314, \mathrm{~F}(8,211)=12.076$, $\mathrm{p}<.01$, and as individual significant predictors, the gender $\mathrm{b}=-.250, \mathrm{t}=-2.531, \mathrm{p}<.05$, employment status $\mathrm{b}=-.205, \mathrm{t}=-3.228, \mathrm{p}<.01$, degree education $\mathrm{b}=-.233, \mathrm{t}=-3.210$, $\mathrm{p}<.01$, monthly personal income $\mathrm{b}=-.304, \mathrm{t}=-5.521, \mathrm{p}<.01$, monthly household income $\mathrm{b}=.274, \mathrm{t}=6.222, \mathrm{p}<.01$ and number of household members $\mathrm{b}=.096, \mathrm{t}=2.158, \mathrm{p}<.05$. The obtained results show that when choosing food for lower educated employed men with lower personal income and higher household income, who live in a larger household, more than for other groups of respondents, the most important is that the food is healthy. Based on the obtained results, it is concluded that this linear combination of predictors proves to be important for predicting certain dependent variables by which we examined the habits of the subjects in nutrition.

\section{Correlation}

Using the Pearson linear correlation coefficient, the interrelationship between the dependent variables by which we examined the subjects eating habits was examined. The obtained results of the correlation matrix are listed in Table 2 and show that the highest degree of dependence was found between regular consumption of fresh fruits and 
vegetables and intake of sufficient water in the body on a daily basis $(r=+0.652, p<.01)$, which means that respondents who regularly consume fresh fruits and vegetables every day also take in a sufficient amount of water in the body and vice versa. The results show that a moderate degree of dependence was also found between the following variables: physical activity and sports $(\mathrm{r}=+0.642, \mathrm{p}<.01)$, which means that with the growth of sports, physical activity increases and vice versa. Then, a moderate correlation was found between the frequency of drinking milk and the frequency of drinking non-carbonated juices $(\mathrm{r}=+0.586, \mathrm{p}<.01)$, which means that with the increase of drinking milk, the frequency of drinking non-carbonated juices increases and vice versa. A moderate correlation was also found between regular consumption of fresh fruits and vegetables and its availability, it the ability of respondents to buy the same in the immediate vicinity $(\mathrm{r}=+0.550, \mathrm{p}<.01)$, which indicates that with the increase in the availability of fresh fruits and vegetables, its regular consumption increases and vice versa.

Table 2. Correlation matrix results

\begin{tabular}{|c|c|c|c|c|c|c|c|c|c|c|c|c|c|c|c|c|}
\hline & 1 & 2 & 3 & 4 & 5 & 6 & 7 & 8 & 9 & 10 & 11 & 12 & 13 & 14 & 15 & 16 \\
\hline 1 & 1 & $.550^{* *}$ & $-.222^{* *}$ & -.066 & $.652^{* *}$ & .046 & .009 & -.119 & -.045 & .101 & $.362^{* *}$ & $.254^{* *}$ & -.056 & $-.265^{* *}$ & $.160^{*}$ & $.139^{*}$ \\
\hline 2 & & 1 & .059 & $.142^{*}$ & $.411^{* *}$ & .095 & .068 & .023 & -.061 & -.041 & $.322^{* *}$ & .071 & -.092 & -.092 & .041 & .131 \\
\hline 3 & & & 1 & $.415^{* *}$ & $-.155^{*}$ & $.302^{* *}$ & $.367^{* *}$ & $.334^{* *}$ & $.173^{*}$ & -.082 & -.130 & $-.165^{*}$ & $-.365^{* *}$ & $.140^{*}$ & .018 & $-.395^{* *}$ \\
\hline 4 & & & & 1 & -.037 & $.322^{* *}$ & $.346^{* *}$ & $.327^{* *}$ & .072 & .030 & $-.352^{* *}$ & $-.228^{* *}$ & -.024 & $.379^{* *}$ & -.033 & $-.206^{* *}$ \\
\hline 5 & & & & & 1 & .072 & -.080 & $-.204^{* *}$ & -.055 & .031 & $.422^{* *}$ & $.286^{* *}$ & -.055 & $-.259^{* *}$ & -.062 & $.189^{* *}$ \\
\hline 6 & & & & & & 1 & $.586^{* *}$ & $.283^{* *}$ & $.163^{*}$ & -.047 & $.199^{* *}$ & .109 & -.033 & .008 & -.060 & $-.148^{*}$ \\
\hline 7 & & & & & & & 1 & $.406^{* *}$ & .132 & .110 & -.018 & .124 & -.020 & .010 & -.076 & $-.135^{*}$ \\
\hline 8 & & & & & & & & 1 & .040 & .086 & $-.198^{* *}$ & -.042 & -.065 & $.182^{* *}$ & $-.142^{*}$ & -.113 \\
\hline 9 & & & & & & & & & 1 & $.315^{* *}$ & $-.169^{*}$ & $-.261^{* *}$ & -.010 & -.097 & .066 & -.078 \\
\hline 10 & & & & & & & & & & 1 & $-.191^{* *}$ & -.053 & $.180^{* *}$ & $-.156^{*}$ & .076 & -.028 \\
\hline 11 & & & & & & & & & & & 1 & $.642^{* *}$ & -.089 & $-.430^{* *}$ & -.008 & $.444^{* *}$ \\
\hline 12 & & & & & & & & & & & & 1 & $-.197^{* *}$ & $-.339^{* *}$ & .063 & $.400^{* *}$ \\
\hline 13 & & & & & & & & & & & & & 1 & $-.208^{* *}$ & $.219^{* *}$ & $.224^{* *}$ \\
\hline 14 & & & & & & & & & & & & & & 1 & -.019 & $-.248^{* *}$ \\
\hline 15 & & & & & & & & & & & & & & & 1 & .085 \\
\hline 16 & & & & & & & & & & & & & & & & 1 \\
\hline
\end{tabular}

$$
* * \mathrm{p}<.01 ; * \mathrm{p}<.05
$$

Source: Author's calculation

\section{Conclusion}

All results obtained by T-test, multiple linear regression and Pearson's correlation coefficient, processing of information and data obtained on the basis of questionnaires related to research of eating habits of the population, on a random sample, can seriously serve all stakeholders of Serbian agricultural sector to answer questions: what, how, how much and for whom to produce.

\section{Conflict of interests}

The authors declare no conflict of interest. 


\section{References}

1. Băncescu, I., Chivu, L., Preda, V., Puente-Ajovín, M., \& Ramos, A. (2019). Comparisons of log-normal mixture and Pareto tails, GB2 or log-normal body of Romania's all cities size distribution. Physica A: Statistical Mechanics and its Applications, 526, 121017.

2. Bulliet, R.W., Crossley, P.K., Headrick, D.R., Johnson, L.L., \& Hirsch, S.W. (2008). The Earth and Its Peoples: A Global History. Volume I. Boston, MA: Houghton Mifflin.

3. Burešova, P., Mrkvova, K., \& Dudić, B. (2020). Changes in gastronomy. Hotel and Tourism Management, 8(1), 79-88. https://doi.org/10.5937/menhottur2001079B

4. Cvijanović, D., Mirčetić, V., \& Vukotić, S. (2020). Impact of cross-clusters and crossindustry collaboration on economic development. September 2020, Conference: 19th International Conference "Life Sciences for Sustainable Development".

5. Cvijanović, D., Simonović, Z., \& Mihailović, B. (2011). Focuses and goals of recent reforms of agrarian and regional policy of the European Union. Economic of Agriculture, vol. 58, no. 3, (pp. 359-370), [in Serbian: Cvijanović, D., Simonović, Z., Mihailović, B. (2011). Težišta i ciljevi novijih reformi agrarne i regionalne politike Evropske unije].

6. Cvijanović, D., Stanišić, T., Leković, M., \& Kostić, M. (2020). Indicators of agricultural and rural development in the East Central and South-East European countries. Agriculture and Forestry, 66 (2): 19-32

7. Cvijanović, D., Vujović, S., \& Maksimović, G. (2018). Mechanisms and specifics of supply and demand functioning on the tourist market. Development Academy of Agriculture of Serbia, Belgrade. [in Serbian: Cvijanović, D., Vujović, S., Maksimović, G. (2018). Mehanizmi i specifičnosti funkcionisanja ponude i tražnje na turističkom tržištu].

8. Cvijanović, D., Pantić, N., \& Ignjatijević, S. (2019). Ekonomska analiza zaposlenosti i BDP-a u zemljama Evropske unije. Ekonomija: Teorija i praksa, 12(4), 11-23. https://doi.org/10.5937/etp1904011C

9. Galbraith, J.K. (2017). Economics in Perspective: A Critical History. Publisher: Princeton University Press.

10. Greenwood, J., Williams, MA, \& Shaw, G. (1990). Policy implementation and tourism in the UK: Implications from recent tourism research in Cornwall. Tourism Management, Volume 11, Issue 1, March 1990, Pages 53- 62.

11. Group of authors. Determinants of Health, in Results of the Population Health Survey of Serbia 2013. Editor: Ilić, D., Institute of Public Health of Serbia "Dr Milan Jovanović Batut". [in Serbian: Grupa autora, Determinante zdravlja, u Rezultati istraživanja zdravlja stanovnišva Srbije 2013. Urednik: Ilić, D].

12. Heilig, G.K. (1996). How Many People Can Be Fed on Earth. Published in The Future Population of the World: What Can We Assume Today? Edited by Wolfgang Lutz (196-251). 
13. Juhász, A., Fazekas, S., \& Győrffy, B., (2016). The hungarian agriculture and food industry in figures, available at: https://www.nak.hu/kiadvanyok/kiadvanyok/1605nak -mmesz2016enweb / file (31.10.2020).

14. Khandpur, N., Cediel, G., Ayala, O.D., Jaime, C.P., \& Parra, C.D. (2020). Sociodemographic factors associated with the consumption of ultra-processed foods in Colombia, available at: https:/www.revistas.usp.br/rsp/article/ view/166395/159135 (31 ${ }^{\text {st }}$ October 2020).

15. Kremer, M. (1993). Population Growth and Technological Change: One Million B.C. to 1990. Q J Econ. 1993; 108 (3): 681-716.

16. Lappe, M.F., Collins, J. \& Rosset, P. (1998). World Hunger. The Institute for Food and Development Policy.

17. Malthus, T.R. (1890). An Essay on the Principle of Population. Sixth Edition, London, Ward, Lock.

18. Milanović, M., Vujović, S., \& Stevanović, S. (2007). Determinants of regionalrural development of Eastern Herzegovina. Paper presented at: The scientific conference-"Multifunctional agriculture and rural development in the Republic of Srpska", Jahorina. [in Serbian: Milanović, M., Vujović, S., Stevanović, S. (2007). Determinante regionalno-ruralnog razvoja Istočne Hercegovine].

19. Montgomery, R.D. (2008). Dirt: The Erosion of Civilizations. Berkeley and Los Angeles. California: University of California Press.

20. Nikolić, M., Nikić, D., Petrović, B., Rančić, N., \& Aranđelović, M. (2009). Influence of food glycemic index and glycemic load on the occurrence of ischemic heart disease, Military Medical Review, Volume 66, No. 3. p. 212. [in Serbian: Nikolić, M., Nikić, D., Petrović, B., Rančić, N., Aranđelović, M. (2009). Uticaj glikemijskog indeksa namirnica i glikemijskog opterećenja ishranom na pojavu ishemijske bolesti srca].

21. Niva, M. (2007). All foods affect health: understandings of functional foods and healthy eating among health-oriented Finns. Appetite. 2007; 48 (3): 384-93 19.

22. Poleman, T. (1981). Quantifying the Nutrition Situation in Developing Countries. Food Research Institute Studies, issue 1, 58.

23. Pomareda, C. (2013). Innovations in the Agriculture of Central America: Progress, Institutional Capacity and Policy Needs, available at: http://www.fao.org/3/ab1732e.pdf (31.10.2020).

24. Popescu, G. H., Sima, V., Nica, E., \& Gheorghe, I. G. (2017). Measuring sustainable competitiveness in contemporary economies-Insights from European economy. Sustainability, 9(7), 1230. https://doi.org/10.3390/su9071230

25. Porter, E. M. (2000). Location, competition and economic development: Local clusters in a global economy. Economic Development Quarterly, 14, 15-34.

26. Rakić, M., Rakić, B., \& Stanojević, Lj. (2019). Encouraging consumer ethnocentrism in the function of domestic foodstuffs consumption, Economics of Agriculture, Year 66, No. 2, 2019, 333-660, Belgrade. 
27. Ronteltap, A., Sijtsema, J.S., Dagevos, H., \& Mariet A de Winter (2012). Construal levels of healthy eating. Exploring consumers' interpretation of health in the food context, Appetite, 59 (2): 333-40. doi: 10.1016 / j.appet.2012.05.023.

28. Samuelson, P. (1969). Economics. Contemporary Administration, Belgrade. [in Serbian: Samuelson, P. (1969), Ekonomija].

29. Sima, V., \& Gheorghe, I. G. (2017). Green Performance Strategies in Romanian Economy in the View of EU 2020 Strategy. In Measuring Sustainable Development and Green Investments in Contemporary Economies (pp. 76-108). IGI Global.

30. Tirol, Ž. (2016). Economics for the common good, Academic book, Novi Sad. [in Serbian: Tirol, Ž. (2016), Ekonomija za opšte dobro].

31. Tošović-Stevanović, A., Ćalović, D., Lalić, G., Žuža, M., \& Cvijanović, G., (2020). Comparative analysis of the economic potential of small and family farms in the Republic of Serbia and Romania, Economics of Agriculture, Vol. LXVII, N³ (6451048).

32. Trišić, I. (2019). Opportunities for sustainable tourism development and nature conservation in Special Nature Reserve "Deliblatska Peščara". Hotel and Tourism Management, 7(1):83-93.

33. Vilke, R., Gedminaite-Raudone, Z., \& Cvijanovic, D. (2019). Future drivers of rural prosperity in knowledge age: Lithuanian case. Economics of Agriculture, Year 66, no. 1, 2019, 1-332, Belgrade.

34. Vujović, S. (2007), Agrotourism in the function of economic development of Vojvodina. Economics of Agriculture, IEP. Vol. LIV, N² (109-260), pp. 215-229. [in Serbian: Vujović, S. (2007). Agroturizam u funkciji razvoja privrede Vojvodine].

35. Williams, A.M. (1988). Tourism and Economic Development, Belhaven Press, London.

36. Wambui, G. A., Judy, K., \& Stephen, M. (2019). Offer quality affecting consumption of hospitality products and services in franchised restaurants in Nairobi Central Business district Kenya. Hotel and Tourism Management, 7(1), 37 - 46. https://doi. org/10.5937/menhottur1901037W 